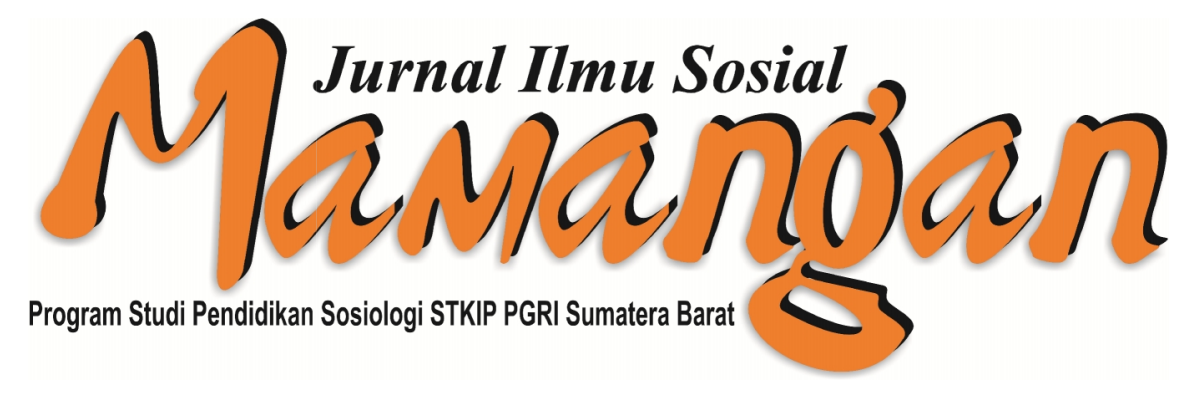

Jurnal Ilmu Sosial Mamangan

Volume 5, Nomor 2, Juli-Desember 2016

Reward Nagari Untuk Negeri

Penulis : : Dian Kurnia Anggreta

Sumber : : Jurnal Ilmu Sosial Mamangan, Volume 5, Nomor 2, Juli-Desember 2016

Diterbitkan Oleh : Laboratorium Pendidikan Sosiologi, STKIP PGRI Sumatera Barat

Untuk Mengutip Artikel ini :

Anggreta, Dian Kurnia,, 2016. Reward Nagari untuk Anak Negeri. Jurnal Ilmu Sosial Mamangan, Volume 5, Nomor 2, Juli Desember 2016: 69-78.

Copyright (C) 2016, Jurnal Ilmu Sosial Mamangan

ISSN : 2301-8496 (Print), ISSN : 2503-1570 (Online)

Laboratorium Pendidikan Sosiologi STKIP PGRI Sumatera Barat 


\title{
Reward Nagari untuk Anak Negeri
}

\author{
Dian Kurnia Anggreta \\ Program Studi Pendidikan Sosiologi STKIP PGRI Sumatera Barat \\ Email : anggreta14@gmail.com
}

\begin{abstract}
This article discusses the activities of Lembaga Peduli Pendidikan Pincuran Madok Pulang (LP3MP) in Nagari Taruang-taruang, Sub District IX Koto Sungai Lasi, regency Solok. This institution was established with Nagari Taruang-taruang communities, to identifying the social problems. One of the problems is low Human Resources. Increases Human Resources conducted with increasing education (human capital), to prepare young people to participate in community life. LP3MP Activities, giving reward to young people, who has accepted into state college (Perguruan Tinggi Negeri). This paper, conduvted from qualitative research with descriptive type. Cata collected through in-depth interviews, non participant observation and study of the document. The purpose of this study describes the process of reward giving to the younger generation since 2011 unitil now.
\end{abstract}

Keywords: Community care education, community empowerment, Reward Nagari

\begin{abstract}
ABSTRAK
Tulisan ini membahas kegiatan Lembaga Peduli Pendidikan Pincuran Madok Pulang (LP3MP) di Nagari Taruang-taruang Kecamatan IX Koto Sungai Lasi Kabupaten Solok. Lembaga ini dibentuk bersama oleh masyarakat, dimulai dari mengidentifikasi persoalan yang dialami oleh masyarakat Nagari Taruang-taruang. Salah satu persoalan yang dirasakan oleh masyarakat adalah relatif rendahnya Sumber Daya Manusia (SDM). Mengingkatkan SDM dilakukan dengan meningkatkan pendidikan yang diyakini sebagai modal dasar manusia, untuk mempersiapkan generasi muda berpartisipasi dalam kehidupan masyarakat. Kegiatan yang dilakukan LP3MP salah satunya memberikan reward kepada masyarakat yang lulus seleksi penerimaan mahasiswa di Perguruan Tinggi Negeri (PTN). Dalam tulisan ini menggunakan metode penelitian kualitatif dengan tipe penelitian deskriptif. Cara mengumpulkan data dengan wawancara mendalam, observasi non partisipan dan studi dokumen. Tulisan ini membahas awal munculnya gagasan dan proses pemberian reward yang telah diberikan sejak tahun 2011 sampai sekarang.
\end{abstract}

Kata Kunci: Masyarakat Peduli Pendidikan, Pemberdayaan Masyarakat, Reward Nagari

\section{PENDAHULUAN}

Pendidikan merupakan bagian yang terpenting untuk menjaga keberlangsungan masyarakat. Emile Durkheim berpendapat, pendidikan membantu generasi muda mempersiapkan diri memasuki kehidupan ditengah masyarakat yang memiliki tata nilai. Pendidikan juga dipandang sebagai baby-sitting agar masyarakat tidak memiliki perilaku menyimpang (social deviat). Pendidikan juga mempersiapkan generasi muda bisa berpartisipasi dalam masyarakat, yang memiliki 
kompleksitas pembagian kerja, dan nilai-nilai kolektif. Dengan demikian pendidikan dipandang sebagai sebuah investasi, karena menurut Durkheim pendidikan berorientasi menyediakan human capital (modal dasar manusia) (Maliki, 2010).

Pendidikan adalah pengajaran karena pendidikan pada umumnya membutuhkan pengajaran dan setiap orang berkewajiban mendidik dan melakukan penanam nilai kepada orang lain (Firdaus, Yasin, \& Anggreta, 2015). Di Indonesia, pendidikan memiliki tiga klasifikasi yang dimuat dalam ketentuan umum, UU No. 20 tahun 2003, tentang Sistem Pendidikan Nasional. Pendidikan diklasifikasikan kepada pendidikan formal, non formal dan informal. Pendidikan formal merupakan jalur pendidikan yang terskruktur dan berjenjang yang terdiri atas pendidikan dasar, pendidikan menengah dan pendidikan tinggi. Pendidikan Nonformal adalah jalur pendidikan di luar pendidikan formal yang dapat dilaksanakan secara terstruktur dan berjenjang. Sedangkan pendidikan informal adalah jalur pendidikan keluarga dan lingkungan (S. N. Republik Indonesia, 2003). Berdasarkan klasifikasi pendidikan formal, nonformal dan informal, pihak yang mendapatkan human capital (modal dasar manusia) adalah anak-anak atau generasi muda. Pemberi human capital pada pendidikan formal adalah guru/dosen, pada pendidikan nonformal adalah guru/pelatih dan sebagainya, serta pada pendidikan informal adalah orang tua serta masyarakat.

Kesemua pihak yang memberi human capital menganut prinsip "bank konsep" dimana mereka memberi "deposan" kepada anak-anak atau generasi muda (Maliki, 2010). Namun tanggung jawab penyelenggaraan pendidikan tidak hanya pada mereka, karena terdapat kewajiban besama orang tua, masyarakat dan pemerintah. Dalam Pasal 11, UU No. 20 tahun 2003, tentang Sistem Pendidikan Nasional, Pemerintah pusat dan daerah wajib memberi layanan dan kemudahan, serta menjamin terselenggaranya pendidikan yang bermutu bagi setiap warga negara tanpa diskriminasi. Pemerintah Pusat dan Daerah wajib menjamin tersedianya dana guna terselenggaranya pendidikan bagi setiap warga negara berusia tujuh sampai lima belas tahun (S. N. Republik Indonesia, 2003). Dapat dipahami penyelenggaraan pendidikan dasar yaitu pada jenjang pendidikan Sekolah Dasar (SD) dan Sekolah Menengah Pertama (SMP) merupakan kewajiban pemerintah pusat dan daerah.
Penyelenggaraan pendidikan dasar diatur dalam Peraturan Pemerintah Republik Indonesia No 47 Tahun 2008, tentang wajib belajar. Penyelenggaraan pendidikan dasar dilakukan tanpa memungut biaya, karena biaya operasional merupakan tanggung jawab pemerintah pusat dan daerah. Fungsi wajib belajar untuk mengupayakan perluasan dan pemerataan kesempatan memperoleh pendidikan yang bermutu bagi setiap warga negara Indonesia, serta memberikan pendidikan minimal bagi warga negera Indonesia untuk dapat mengembangkan potensi dirinya agar dapat hidup mandiri di dalam masyarakat atau melanjutkan pendidikan ke jenjang yang lebih tinggi (M. H. dan H. A. M. Republik Indonesia, 2008). Berbicara tentang penyelenggaraan pendidikan menengah dan tinggi, pemerintah pusat dan daerah juga mempunyai andil, namun tidak menanggung sepenuhnya biaya operasional ke dua jenjang pendidikan tersebut.

Perhatian pemerintah daerah dalam pendidikan diantaranya ditulis oleh Fajar Sidik dalam tulisannya yang berjudul Implementasi Program Jaminan Pendidikan Daerah di Kota Yogyakarta. Tulisan tersebut membahasa tentang program Jaminan Pendidikan Daerah (JPD) di Kota Yogyakarta yang menyediakan bantuan kepada para siswa yang berasal dari keluarga miskin, terdaftar dalam Kartu Menuju Sejahtera (KMS), agar dapat mengakses pendidikan pada jenjang TK sampai SMA. Dari hasil penelitian menunjukkan bahwa implementasi program JPD belum efektif karena akses, bias, cakupan dan ketepatan layanan belum efektif dilaksanakan, disamping itu motivasi dan prestasi belajar siswa KMS relatif rendah (Sidik, 2015). Tulisan Fajar Sidik membahas implementasi program JPD yang dibuat Pemerintah Kota Yogyakarta, berdasarkan temuannya belum efektif, merupakan penelitian yang fokus pada peran pemerintah dalam meningkatkan akses masyarakat terhadap pendidikan yang bersifat topdown.

Berbeda dengan tulisan ini yang membahas kegiatan yang dilaksanakan oleh lembaga yang dibangun bersama oleh Masyarakat dan pemerintah Nagari (LP3MP) dalam mendukung pendidikan. Kegiatan yang dibuat LP3MP bukan berasal dari program pemerintah daerah, yang dikenal dengan pendekatan bottom up. Karena LP3MP berdiri dan merumuskan kegiatan berdasarkan idenfitikasi persoalan yang dialami masyarakat, dan merumuskan sendiri kegiatan yang dilakukan, untuk mengatasi persoalan 
tersebut (Mendukung masyarakat melanjutkan pendidikan pada jenjang Peguruan Tinggi).

Dukungan terhadap pendidikan yang dilakukan di Masyarakat Nagari Taruangtaruang Kecamatan IX Koto Sungai Lasi Kabupaten Solok, adalah dengan memberikan reward kepada masyarakat yang lulus seleksi penerimaan mahasiswa baru di Perguruan Tinggi Negeri (PTN). Masyarakat, Pemerintah Nagari, Kerapatan Adat Nagari (KAN), dan Badan Musyawarah (Bamus) Nagari, bersamasama membentuk LP3MP. Reward diberikan berbentu uang senilai $\mathrm{Rp} 1.000 .000$ per masingmasing penerima (lulus seleksi PTN). Kegiatan pemberian reward tersebut telah dilakukan semenjak tahun 2011. Sebanyak 96 orang masyarakat (generasi muda) yang lulus seleksi penerimaan mahasiswa di PTN telah menerima reward, untuk lebih jelas dapat dilihat pada tabel berikut:

\section{Tabel 1}

Data Penerima Reward Per Tahun

\begin{tabular}{|c|c|c|}
\hline No & Tahun & $\begin{array}{c}\text { Penerima } \\
\text { Reward }\end{array}$ \\
\hline 1. & 2011 & 11 \\
\hline 2. & 2012 & 13 \\
\hline 3. & 2013 & 27 \\
\hline 4. & 2014 & 16 \\
\hline 5. & 2015 & 16 \\
\hline 6. & 2016 & 13 \\
\hline \multicolumn{2}{|c|}{ Jumlah } & $\mathbf{9 6}$ \\
\hline
\end{tabular}

Sumber: Dokumen LP3MP Nagari Taruangtaruang Kec. IX Koto Sungai Lasi, Kab. Solok, 2016

Pemberian reward menarik untuk ditelusuri karena wujud kepedulian masyarakat bersama pemerintah Nagari dalam bidang pendidikan guna Meningkatkan SDM. Berdasarkan temuan penelitian, penerima reward terbantu oleh kegiatan LP3MP tersebut, karena dapat dipergunakan untuk biaya registrasi pada PTN tempat yang bersangkutan dinyatakan lulus seleksi, serta digunakan untuk menambah biaya hidup. Penerima reward adalah masyarakat Nagari Taruang-taruang baik yang berdomisili di Nagari Taruang-taruang, dan keturunan ${ }^{1}$ masyarakat Nagari Taruang-taruang, dalam tulisan ini disebut sebagai calon mahasiswa lulus seleksi PTN.

${ }^{1}$ Konsep keturunan di sini adalah anak-anak yang ayah atau ibunya berasal dari Nagari Taruangtaruang dimana mereka tidak tinggal di Nagari tersebut (merantau), namun mereka juga lulus seleksi penerimaan mahasiswa di PTN
Kegiatan pemberian reward ini digagas oleh masyarakat dan pemerintah Nagari, tidak muncul begitu saja. Gagasan ini muncul berdasarkan musyawarah bersama dalam mengidentifikasi persoalan yang dialami masyarakat dan solusi yang ditawarkan dalam menyelesaikan persoalan tersebut. Dalam tulisan ini memfokuskan pembahasan tentang: Mendeskripsikan proses pemberian reward kepada Calon mahasiswa lulus seleksi PTN.

Aktifitas yang dilakukan oleh LP3MP yang dibentuk masyarakat bersama pemerintah Nagari dalam tulisan ini disebut sebagai partisipasi dalam pemberdayaan masyarakat meningkatkan sumberdaya manusia. Partisipasi dapat didefinisikan dengan berbagai sudut pandang, ada yang mendefinisikan sebagai kontribusi sukarela dari masyarakat kepada proyek tanpa ikut serta dalam pengambilan keputusan. Partisipasi juga dinyatakan sebagai "pemekaan" (membuat peka) pihak masyarakat untuk meningkatkan kemauan menerima dan kemampuan untuk menanggapi proyek-proyek pembangunan. Partisipasi juga dapat didefinisikan sebagai keterlibatan sukarela oleh masyarakat dalam perubahaan yang ditentukannya sendiri (Mikkelsen, 2003). Definisi partisipasi pada prinsipnya merupakan keterlibatan masyarakat, namun keterlibatan dalam pemberdayaan masyarakat disini diklasifikasikan: pertama, terlibat dalam program yang dibuat oleh pemerintah topdown, kedua terlibat dalam kegiatan yang ditentukan sendiri oleh masyarakat. Pemberian reward merupakan klasifikasi kedua.

Tulisan yang membahas tentang Pemberdayaan masyarakat Desa pernah ditulis oleh Ulumiyah et.al, dengan judul Peran Pemerintah Desa dalam Memberdayakan Masyarakat Desa, studi pada Desa Sumberpasir Kecamatan Pakis Kabupaten Malang. Penelitian tersebut membahas peran dan upaya Pemerintah Desa dalam pemberdayaan, serta membahas faktor pendukung dan penghambat dalam pemberdayaan. Hasil penelitian menunjutkan peran Pemerintah Desa dalam pemberdayaan terdapat tiga, yaitu: Peran sebagai pelaksana kebijakan, pelaksanan program dan pembina dalam bidang ekonomi, kesehatan dan keagamaan. Untuk upaya pemerintah desa dalam pemberdayaan Desa dengan mengaktifkan UPK (pinjaman dengan bunga rendah) serta meningkatkan peran serta masyarakat dalam berbagai kegiatan Desa. Faktor pendukung pemberdayaan masyarakat ini adalah terdapat kerjasama Pemerintah Desa 
dengan Swasta dan tersedia anggaran dana. Namun Faktor penghambat masyarakat Desa kurang berpartisipasi, budaya malas dan keterbatasan fasilitas pendukung dalam kegiatan (Ulumiyah, Gani, \& Mindarti, 2013).

Pemberdayaan masyarakat juga pernah ditulis oleh Kurniawati et.al, yang berjudul, Pemberdayaan Masyarakat di Bidang Usaha Ekonomi; Studi pada Badan Pemberdayaan Masyarakat Kota Mojokerto. Tulisan tersebut membahas program yang telah dilaksanakan oleh Badan Pemberdayaan Masyarakat Kota Mojokerto dengan memberikan bantuan perorangan dan bantuan lembaga, dapat meningkatakan produktivitas dan pendapatan masyarakat penerima bantuan. Yang perlu dilakukan adalah mengoptimalkan kerja Badan Pemberdayaan Masyarakat tersebut (Kurniawati, Supriyano, \& Hanafi, 2013). Studi pemberdayaan juga dibahas oleh Firdaus dalam proyek pembangunan sosial di kawasan Hutan Mbeliling, NTT. Namun studi ini lebih menekankan perhatian pada evaluasi proyek pemberdayaan (Firdaus, 2016)

Tulisan Reward Nagari untuk Anak Negari ini juga membahas tentang pemberdayaan yang dilakukan oleh Masyarakat bersama dengan pemerintah Desa (dalam tulisan ini disebut Nagari), namun tulisan Ulumiyah, et.al dan Kurniawati et.al memfokuskan pada pemberdayaan masyarakat bidang ekonomi, sedangkan tulisan ini membahas pemberdayaan masyarakat pada bidang pendidikan.

\section{METODE PENELITIAN}

Penelitian dilakukan pada bulan Mei sampai Agustus 2016. Metode penelitian yang digunakan adalah metode penelitian kualitatif yang merupakan metode penelitian ilmu-ilmu sosial yang mengumpulkan dan menganalisis data berupa kata-kata lisan maupun tulisan, serta data perbuatan-perbuatan (Afrizal, 2008). Cara mengumpulkan data dengan wawancara mendalam, sehingga dapat menggali informasi tentang awal mula muncul gagasan serta proses pemberian reward. Observasi non partisipasi dengan mengamati kegiatan yang dilaksanakan LP3MP seperti pendataan calon penerima reward, pengumpulan donasi dan penyerahan reward. Selain itu juga dilakukan studi dokumen yang diperoleh dari pihak walinagari dan LP3MP.

Informan penelitian diperoleh secara Purposive, merupakan cara mendapatkan informan dengan menetapkan kriteria-kriteria tertentu yang mesti dipenuhi pihak yang menjadi sumber informasi. Kriteria informan adalah: 1). Pengurus LP3MP dan 2). Terlibat aktif dalam pelaksanaan kegiatan pemberian reward. Selain pengurus LP3MP juga diwawancarai Wali Nagari, pemuda, guru yang berdomisili di Nagari Taruang-taruang, penerima reward, serta keluarga penerima reward.

\section{LATAR BELAKANG GAGASAN PEMBERIAN REWARD}

Gagasan pemberian reward untuk calon mahasiswa lulus seleksi PTN ini muncul saat Musyawarah Nagari. Musyawarah tersebut diadakan oleh pemerintah nagari pada tanggal 28 Desember 2008 di Kantor Wali Nagari. Musyawarah dimulai jam 10.00 sampai 17.00 WIB tersebut dihadiri oleh 40 orang yang terdiri dari pihak Pemerintah Nagari, KAN, Bamus, guru yang berasal dan bertempat tinggal (berdomisili) di Nagari, pemuda dan masyarakat. Berdasarkan informasi yang disampaikan oleh pengurus LP3MP dan pihak nagari yang mengikuti Musyawarah sampai selesai berjumlah 18 orang.

Musyawarah tersebut membahas persoalan yang dialami oleh masyarakat. Pertemuan ini dimulai dengan mengindentifikasi persoalan yang dihadapi oleh masyarakat. Dalam proses pengidentifikasian ini peserta diminta untuk menyebutkan persoalan yang dialami oleh masyarakat. Muncul tanggapan dari peserta musyawarah seperti:

1. Kantor Wali Nagari kurang layak untuk melayani urusan administrasi masyarakat

2. Sumber daya manusia rendah

3. Produksi pertanian rendah

4. Masyakat tidak mau memberikan tanah untuk pembangunan jalan

5. Tidak merata kepemilikan lahan

Tidak hanya mengidentifikasi persoalan yang terjadi di Nagari, dalam musyawarah tersebut diurai penyebab dan alternatif pemecahan. Semua peserta musyarawah mendapat kesempatan berpendapat dan menyampaikan usulan. Untuk lebih jelasnya persoalan yang diidentifikasi, penyebab dan alternatif yang diusulkan dapat dilihat pada tabel berikut: 
Tabel. 2

Hasil Identifikasi Persoalan Di Nagari Tarung-tarung

\begin{tabular}{|c|c|c|c|}
\hline No. & Persoalan & Penyebab & Pemecahan \\
\hline 1. & $\begin{array}{l}\text { Kantor Wali Nagari Kurang } \\
\text { Layak }\end{array}$ & Bangunan relatif tua & $\begin{array}{l}\text { Perbaikan kantor wali } \\
\text { nagari }\end{array}$ \\
\hline 2. & $\begin{array}{l}\text { Sumber Daya Manusia (SDM) } \\
\text { rendah }\end{array}$ & $\begin{array}{l}\text { Tingkat pendidikan masyarakat } \\
\text { relatif rendah }\end{array}$ & $\begin{array}{l}\text { Meningkatkan } \\
\text { kesadaran masyarakat } \\
\text { akan pendidikan }\end{array}$ \\
\hline 3. & Produksi pertanian rendah & $\begin{array}{l}\text { Terdapat sawah tadah hujan, } \\
\text { kondisi tanah dikategorikan } \\
\text { kurang subur dan penggunaan } \\
\text { bibit non unggul }\end{array}$ & $\begin{array}{l}\text { Pembangunan aliran } \\
\text { Irigasi, pengolahan } \\
\text { tanah dengan } \\
\text { pemupukan teratur, } \\
\text { menggunakan bibit } \\
\text { unggul }\end{array}$ \\
\hline 4. & $\begin{array}{l}\text { Masyarakat tidak mau } \\
\text { memberikan tanah untuk } \\
\text { pembangunan jalan }\end{array}$ & Ketidak jelasan ganti rugi & Jelas aturan ganti rugi \\
\hline 5. & Tidak merata kepemilikan lahan & $\begin{array}{l}\text { Bertambahnya jumlah penduduk } \\
\text { dan migrasi pendatang }\end{array}$ & $\begin{array}{l}\text { Peraturan Nagari } \\
\text { tentang pengaturan } \\
\text { pemakaian tanah }\end{array}$ \\
\hline
\end{tabular}

Sumber: Dokumen LP3MP Nagari Taruang-taruang Kec. IX Koto Sungai Lasi, Kab. Solok, 2011

Persoalan Kondisi Kantor Wali Nagari kurang layak untuk ditempati karena kondisi bangunan relatif tua, dari hasil pertemuan perlu ada perbaikan bangunan kantor dan akan diusulkan pembiayaan dari APBD. Sumber Daya Manusia rendah diyakini oleh masyarakat karena tingkat pendidikan masyarakat relatif rendah dan pemecahannya meningkatkan kesadaran masyarakat akan pendidikan. Ini yang menjadi fokus dalam tulisan dan diulas lebih lanjut dibawah ini. Produksi pertanian rendah penyebabnya terdapat sawah tadah hujan. Hal ini sesuai dengan temuan data penggunaan lahan bahwa sawah irigasi dengan luas $175 \mathrm{Ha}$, jumlah ini lebih sedikit dibandingkan dengan sawah tadah hujan seluas 363 Ha (Profil Nagari Tarung-tarung, 2015). Kondisi tanah kurang subur dan penggunaan bibit non unggul. Pemecahan persoalan untuk meningkatkan produksi pertanian dengan memperbanyak aliran arigasi, pengolahan dan pemupukan secara teratur, serta pihak Nagari akan mengupayakan pengadaan bibit unggul dengan bekerjasama Dinas Pertanian Kabupaten Solok, pada tanaman padi, jagung, kedele, kakao, manggis dan durian, yang merupakan komoditi tanam di Nagari ini. Persoalan masyarakat tidak mau memberikan tanah untuk pembangunan jalan, upaya yang dilakukan oleh Pemerintah Nagari, beserta niniak mamak memberikan sosialisasi tentang jalan sebagai salah satu penunjang kegiatan ekonomi, serta memberikan kejelasan proses ganti rugi. Persoalan tidak meratanya kepemilikan lahan dalam pertemuan pemecahannya dengan membuat Peraturan
Nagari tentang pengaturan pemilikan lahan, namun belum ditemukan Peraturan Nagari tersebut dan sistem seperti apa yang akan diberlakukan.

Kembali kepersoalan SDM yang rendah, dalam Musyawarah tersebut disampaikan SDM rendah karena pendidikan dimiliki masyarakat relatif rendah. Masyarakat diharapkan memiliki pendidikan tinggi agar persoalan ini bisa diatasi. Dalam diskusi tersebut juga disampaikan bahwa tidak "terdengar" anak Nagari Taruang-taruang yang kuliah, karena tahun-tahun sebelumnya masyarakat masih mendapatkan informasi terdapat anak Nagari yang kuliah ke Perguruan Tinggi. Dari penelusuran, tidak ditemukan data masyarakat Nagari yang sedang kuliah, namun data yang ada menentukan penduduk berdasarkan tingkat pendidikan, untuk lebih jelas dapat dilihat pada tabel berikut:

Tabel 3

Data Penduduk Berdasarkan Tingkat Pendidikan Tahun 2007

\begin{tabular}{|c|l|c|}
\hline No. & \multicolumn{1}{|c|}{ Tingkat Pendidikan } & $\begin{array}{c}\text { Jumlah } \\
\text { Penduduk }\end{array}$ \\
\hline 1. & Sekolah Dasar & 1.067 \\
\hline 2. & Sekolah Menengah Pertama & 689 \\
\hline 3. & Sekolah Menengah Atas & 271 \\
\hline 4. & Perguruan Tinggi & 35 \\
\hline \multicolumn{2}{r}{ Jumlah } & 2.062 \\
\hline
\end{tabular}

Sumber: Profil Nagari Tarung-tarung tahun 2007

Berdasarkan data tabel 3 jumlah penduduk Nagari Tarung-tarung yang lulusan Perguruan 
Tinggi sejumlah 35 orang. Namun belum membuktikan ada atau tidak, serta jumlah masyarakat yang melanjutkan pendidikan ke Perguruan Tinggi tahun 2007 dan 2008. Pendapat peserta Musyawarah tentang tidak "terdengar" Masyarakat yang melanjutkan pendidikan ke Perguruan Tinggi, berdasarkan informasi yang diperoleh dari Niniak Mamak dan pihak Pemerintah Nagari, karena kedua pihak tersebut memiliki akses dalam mengetahui informasi yang terjadi di Nagari termasuk masyarakat yang melanjutkan pendidikan ke Perguruan Tinggi.

Persoalan rendahnya SDM di Nagari diyakini masyarakat karena tingkat pendidikan yang relatif rendah, dalam pertemuan tersebut disampaikan bahwa pendidikan dianggap sebagai modal bagi masyarakat sehingga kelak memiliki pengetahuan dan mampu memperbaiki perekonomian. Namun untuk mendapatkan pendidikan, hingga ke jenjang Perguruan Tinggi, masyarakat mengalami kendala, seperti:

1. Ketatnya seleksi masuk Perguruan Tinggi

2. Tidak punya biaya (Persoalan Ekonomi)

Kendala tersebut diurai agar menemukan solusi, sehingga persoalan ketatnya seleksi masuk Perguruan Tinggi masyarakat memberikan bimbingan belajar untuk siswa di Nagari Tarung-tarung. Sedangkan persoalan biaya memang belum sepenuhnya dirumuskan penyelesaiannya.

Musyawarah

menghasilkan pengidentifikasian persoalan yang dialami masyarakat Nagari Tarung-tarung, penyebab dan pemecahan yang akan dilakukan. Proses pelaksanaan pemecahan dimulai pada tahun 2010, hal ini bukan berarti tidak ada pergerakan yang dilakukan semenjak Musyawarah Nagari tahun 2008. Relatif banyak terjadi pertemuanpertemuan tokoh masyarakat dan Pemerintah Nagari. Dalam pertemuan dalam rentang waktu 2008 sampai 2010, muncul gagasan membentu membentuk Lembaga yang diberinama Lembaga Peduli Pendidikan Pincuran Madok Pulang (LP3MP), yang menjadi wadah penyelesaian persoalan rendahnya SDM.

\section{PEMBENTUKAN LEMBAGA PEDULI PENDIDIKAN PINCURAN MADOK PULANG (LP3MP) NAGARI TARUANG- TARUANG}

Menyelesaikan persoalan rendahnya SDM, dibentuk LP3MP Nagari Taruang-taruang pada tanggal 3 Juli 2010. Pembentukan tersebut dilakukan dalam Musyawarah Nagari saat itu dihadiri oleh Pemerintah Nagari, KAN, Bamus, guru yang berdomisili di Nagari Tarung-tarung dan pemuda. Pertemuan ini yang kedua setelah tahun 2008. Musyawarah yang dilaksanakan di Gedung Serbaguna Nagari Tarung-tarung tersebut mencapai kesepakatan bahwa dibentuk LP3MP. Lembaga ini merupakan lembaga yang didirikan bersama yang konsen terhadap peningkatan pendidikan di Nagari Taruangtaruang. Lembaga ini diberinama Lembaga Peduli Pendidikan Pincuran Madok Pulang. Secara harfiah, Pincuran merupakan konsep lokal yang bermaksud air yang mengalir kebawah, ini dipahami sebagai pemberian atau pencerahan. Sedangkan Madok Pulang bertujuan menghimbau perantau untuk memberhatikan daerah asal. Dapat disimpulkan nama lembaga ini memiliki arti Lembaga peduli pendidikan yang dibangun masyarakat bersinergi dengan perantau bertujuan untuk memberi pencerahan bagi seluruh masyarakat.

Pertemuan tersebut ditetapkan kantor sekretarian LP3MP berkedudukan di Kantor Wali Nagari Taruang-taruang Kecamatan IX Koto Sungai Lasi Kabupaten Solok. Kemudian dipilih pengurus LP3MP masa jabatan 20102015. Adapun nama pengurus tertera dalam tabel berikut:

\section{Tabel 4}

Pengurus LP3MP Nagari Taruang-taruang

\begin{tabular}{|c|l|l|}
\hline No. & \multicolumn{1}{|c|}{ Jabatan } & \multicolumn{1}{c|}{ Nama } \\
\hline 1. & Ketua & H. Sjamsuardi, SE \\
\hline 2. & Ketua I & Drs. Syahrisal Kimin \\
\hline 3. & Ketua II & Drs. Djufrizal Wahab \\
\hline 4. & Ketua III & Arman, S.Pd \\
\hline 5. & Sekretaris & Drs. Syaharuddin \\
\hline 6. & Wakil Sekretaris & Zulkifli, A.Md \\
\hline 7. & Bendahara & H. Ali Amsar, AmaE \\
\hline 8. & $\begin{array}{l}\text { Bidang Komunikasi } \\
\text { \& Informasi }\end{array}$ & Martison, S.Pd, M.Pd \\
\hline 9. & Bidang Pendidikan & Afdal Piyasmi, SSn \\
\hline 10. & Bidang Dana & Ir. Hendri Martius \\
\hline
\end{tabular}

Sumber: SK Wali Nagari Tarung-tarung No: 19/ WN-2010, tentang Susunan Pengurus LP3MP

Dirumuskan pembagian tugas pada masingmasing pengurus, seperti tugas ketua mengkoordinir kegiatan LP3MP, memimpin rapat pengurus dan rapat umum. Sekretaris melaksanakan kegiatan administrasi. Bendahara mebuat buku kas LP3MP, menerima uang dari donor dan membayarkan uang kepada penerima reward setelah disetujui oleh ketua. Bidang 
Komunikasi dan Informasi memberikan informasi kegiatan LP3MP pada masyarakat Nagari Taruang-taruang dan perantau. Bidang Dana melakukan pengumpulan dana untuk mendukung kegiatan LP3MP. Bidang Pendidikan mengkoordinir kegiatan bimbingan belajar dan pemberian reward.

Pengurus LP3MP yang dijelaskan diatas merupakan merupakan struktur dalam tubuh LP3MP itu sendiri. Lembaga ini dalam melaksanakan kegiatan didukung oleh berbagai pihak, untuk lebih mudah memahami dapat dilihat dalam gambar berikut:

\section{Gambar 1 \\ Stakholder Kegiatan Lembaga LP3MP}

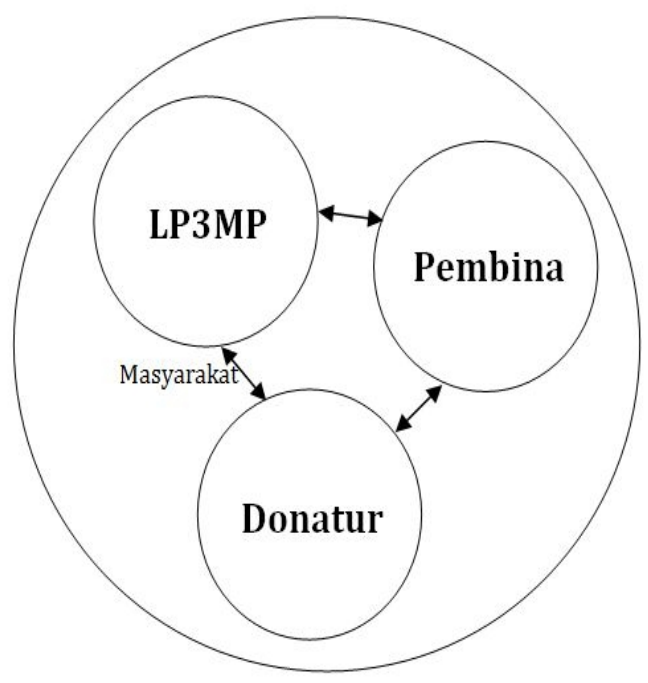

Fungsi LP3MP menjalankan kegiatan peduli pendidikan sesuai dengan tujuan didirikan lembaga tersebut, di Nagari Taruangtaruang. Pembina yang terdiri dari Pemerintah Nagari, KAN dan Bamus berfungsi memberikan pembinaan pada LP3MP. Donatur terdiri dari masyarakat dan perantau yang mendukung kegiatan dilaksanakan oleh lembaga, baik berupa materi, ide dan partisipasi.

Selain penetapan pengurus juga dirumuskan kegiatan yang dilaksanakan, yaitu:

1. Memberikan bimbingan belajar terhadap siswa Sekolah Dasar Kelas V dan VI, siswa Sekolah Menengah Pertama dan Sekolah Menengah Atas untuk mata pelajaran yang diujikan pada Ujian Nasional

2. Memberikan bantuan bagi masyarakat Nagari Taruang-taruang yang diterima pada PTN di seluruh wilayah Republik Indonesia
3. Memberikan pinjaman kepada masyarakat Nagari Taruang-taruang kurang mampu yang di terima di PTN

4. Menumbuhkan rasa cinta bernagari bagi masyarakat Nagari Taruang-taruang

5. Menumbuh kembangkan keluarga peduli cinta pendidikan.

\section{KEGIATAN LP3MP NAGARI TARUANG- TARUANG}

Kegiatan yang dilaksanakan oleh LP3MP Nagari Taruang-taruang dimulai dengan memberikan bimbingan belajar kepada siswa SD Kelas V dan VI, siswa SMP kelas IX dan SMA kelas XII. Bimbingan belajar ini bertujuan mengingkatkan kualitas dan kuantitas lulusan masing-masing jenjang pendidikan. Kegiatan pemberian bimbingan belajar diawali dengan pendataan siswa dan guru yang berdomisili di Nagari Taruang-taruang oleh pengurus bidang pendidikan. Pengurus juga bekerja sama dengan pihak sekolah seperti SMP N 2 Sungai Lasi, MTsN Sungai Lasi, SMA N 1 Sungai Lasi. Kerjasama bertujuan untuk membuat program pendidikan berdasarkan jenjang pendidikan yang dimiliki siswa. Kemudian dilakukan sosialisasi kepada guru dan siswa pada Agustus 2010. Dalam sosialisasi disampaikan kegiatan bimbingan belajar dan menyepakati waktu pelaksanaan bimbingan belajar. Matapelajaran yang diajarkan disesuaikan dengan mata pelajaran yang diujikan pada Ujian Nasional. Jumlah guru yang memberikan bimbingan belajar berjumlah 6 orang. Dan kegiatan ini rutin dilaksanakan setiap sabtu sore dan minggu mulai tahun 2010.

Memberikan bantuan (reward) pada calon mahasiswa lulus seleksi PTN juga kegiatan tahunan yang dilakukan oleh LP3MP. Reward diberikan sebesar Rp1.000.000 kepada calon mahasiswa lulus seleksi PTN tersebut. Alasan diberikan reward berdasarkan hasil musyawarah masyarakat, untuk membantu biaya melanjutkan pendidikan ke Perguruan Tinggi. Masyarakat menyadari seleksi penerimaan mahasiswa baru di PTN relatif ketat, karena sangat diminati. Diterima di PTN dianggap sebagai prestasi bagi masyarakat. Hal juga dibenarkan oleh ketua pengurus LP3MP, seperti kutipan wawancara berikut:

"Reward ini diberikan kepada masyarakat yang diterima di PTN, karena sulit untuk masuk PTN dan banyak pesaing. Masuk PTN lulus pertama ini sangat sulit, jika lulus berarti anak-anak kita ini merupakan anak berprestasi." 
Pemberian reward ini dilakukan sejak tahun 2011 sampai sekarang. Tujuan pemberian reward ini membantu masyarakat dalam membiayai melanjutkan pendidikan ke Perguruan Tinggi. Pemberian reward diyakini oleh pengurus belum membantu secara penuh biaya dalam melanjutkan pendidikan masyarakat Nagari Taruang-taruang ke Perguruan Tinggi. Namun dengan diberikan reward ini masyarakat terbantu, karena bisa menjadi tambahan biaya untuk registrasi di Perguruan Tinggi tempat mereka diterima, serta membantu biaya kebutuhan lainnya. Selain membatu bagi penerima reward bertujuan untuk menumbuhkan rasa bernagari pada masyarakat Nagari Taruang-taruang. Karena kegiatan ini melibatkan berbagai pihak seperti LP3MP, Pemerintah Nagari, KAN, Bamus, selaku pembina. Pendonor yang terdiri dari masyarakat Nagari Taruang-taruang dan para perantau. Sebagai pembina LP3MP, Pemerintah Nagari, KAN dan Bamus mendukung setiap kegiatan lembaga tersebut. LP3MP melaksanakan kegiatan agar tercapai tujuan tujuan memecahkan persoalan rendahnya Sumber Daya Manusia di Nagari ini yang disebut.

\section{PROSES PEMBERIAN REWARD}

1. Pengumpulan dana

Pengumpulan dana untuk kegiatan pemberian reward ini dilakukan oleh pengurus LP3MP bidang dana. Pengumpulan dana sudah dimulai dari tahun Agustus 2010. Pengumpulan dana ini sebelumnya sudah dibahas pada Musyawarah Nagari. Pengurus LP3MP meminta bantuan dari masyarakat dan para perantau yang tergabung dalam Ikatan Warga Taruang-taruang (IWARTA).

Bantuan yang diberikan oleh masyarakat yang memiliki penghasilan tetap ditetapkan sejumlah Rp 10.000 sampai Rp 100.000. Untuk mengumpulkannya Pengurus LP3MP mendatangi rumah masyarakat, setiap bulan. Selain bantuan tersebut, juga diterima infak, zakat, sedekah yang langsung diberikan kepada pengurus oleh masyarakat. Bantuan dari para perantau dikoordinir oleh IWARTA masing-masing daerah seperti Solok, Padang, Jakarta, Pekanbaru, Medan dan diserahkan kepada penguruh LP3MP. Infak, zakat dan sedekah yang diperoleh pada saat hari besar agama seperti Idul Fitri dan Idul Adha juga dialokasikan untuk menambah dana yang dikumpulkan oleh LP3MP, dengan catatan tidak bertentangan dengan peraturan perundang-undangan yang berlaku.

Dana yang dikumpulkan oleh pengurus diserahkan kepada bendahara LP3MP, selambat-lambatnya $3 \times 24$ jam setelah uang diterima. Hal ini bertujuan agar tidak terjadi kesalahan dalam pembukuan. Dana yang telah terkumpulkan tersebut untuk membiayai kegiatan yang dilakukan oleh LP3MP dan pemberian reward.

Berdasar data yang diperoleh dari tahun 2011-2016, sejumlah 96 orang masyarakat yang telah mendapatkan, dan masingmasing penerima memperoleh RP1.000.000. Total dana yang telah dikeluarkan untuk pemberian reward tersebut sebesar Rp 96.000.000. Untuk rincian pertahun dapat dilihat pada tabel berikut:

Tabel 5

\begin{tabular}{|c|l|c|c|}
\hline No & Tahun & $\begin{array}{c}\text { Jumlah } \\
\text { Penerima } \\
\text { Reward }\end{array}$ & Dana reward \\
\hline 1. & 2011 & 11 & $\mathrm{Rp} 11.000 .000$ \\
\hline 2. & 2012 & 13 & $\mathrm{Rp} 13.000 .000$ \\
\hline 3. & 2013 & 27 & $\mathrm{Rp} 27.000 .000$ \\
\hline 4. & 2014 & 16 & $\mathrm{Rp} 16.000 .000$ \\
\hline 5. & 2015 & 16 & $\mathrm{Rp} 16.000 .000$ \\
\hline 6. & 2016 & 13 & $\mathrm{Rp} 13.000 .000$ \\
\hline \multicolumn{2}{|c|}{ Jumlah } & $\mathbf{9 6}$ & $\mathrm{Rp} 96.000 .000$ \\
\hline
\end{tabular}

Sumber: Dokumen LP3MP Nagari Taruangtaruang Kec. IX Koto Sungai Lasi, Kab. Solok, 2016

Berdasarkan data tersebut jumlah penerima reward paling besar dibandingkan tahun lainnya. Pada saat itu dana yang dikumpulkan dari masyarakat dan perantau tidak cukup untuk memberikan reward, cara yang ditempuh pengurus LP3MP dengan mengajukan proposal permohonan bantuan kepada Pemerintah Kabupaten Solok dan Provinsi Sumatera Barat. Tahun 2013 tersebut bantuan dari Pemerintah Kabupaten Solok diperoleh sebesar Rp 10.000.000 dan dari Pemerintah Provinsi Sumatera Barat sebesar Rp 7.500.000.

Persoalan keterbatasan dana juga dirasakan sebagai kendala oleh pengurus. Seperti mengumpulkan bantuan dari masyarakat, hal ini dikarenakan fluktuatif pendapatan masyarakat. Pengurus LP3MP menyadari tidak mungkin sepenuhnya mengandalkan bantuan dari masyarakat dan 
perantau, sehingga Nagari menargetkan membuka unit usaha budidaya ikan. Usaha ini pernah dibangun di tanah Nagari yang dibuatkan kolam ikan, namun tahun 2015, dinding kolam tersebut jebol disebabkan oleh banjir.

2. Pendataan Calon Mahasiswa Lulus Seleksi PTN

Pendataan calon mahasiswa lulus seleksi PTN dilakukan oleh bidang pendidikan. Pendataan dilakukan dengan mencari informasi dan menerima laporan dari masyarakat jika terdapat keluarga, kerabat dan tetangga mereka yang diterima di PTN. Pendataan dilakukan dengan cara memperlihatkan bukti lulus seleksi PTN. Disamping bukti lulus seleksi diminta melengkapi berkas administrasi seperti foto dan membuat surat pernyataan bahwa yang bersangkutan akan belajar sungguhsungguh, rajin, tidak terlibat dalam tawuran dan penyalahgunaan narkoba, serta akan tetap mengabdi pada Nagari Taruangtaruang.

Data yang terkumpul direkap dan akan dilaporkan pada kegiatan-kegiatan Nagari, seperti musyawarah nagari, diumumnya setelah penyelenggaraan sholat idul fitri dan idul adha. Tujuannya agar masyarakat dapat selalu mengetahuai kegiatan yang dilaksanakan oleh LP3MP. Selain itu pelaporan jumlah penerima reward diharapkan akan menstimulus masyarakat untuk melanjutkan pendidikan sampai Perguruan Tinggi.

\section{Penyerahan Reward}

Penyerahan reward dilakukan di gedung serbaguna Nagari Taruang-Taruang. Waktu penyerahan dilakukan sebelum keberangkatan calon mahasiswa baru melakukan registrasi di kampus. Waktu penyerahan reward sampaikan kepada keluarga penerima reward, penerima dianjurkan untuk mengikuti acara penyerahan tersebut. Kegiatan ini dihadiri oleh Pemerintah Nagari, KAN, Bamus dan para undangan lain.

Kegiatan ini diawali dengan laporan kegiatan LP3MP, penyampaian materi motivasi yang narasumbernya merupakan masyarakat dan perantau Nagari Taruangtaruang yang berhasil agar meningkatkan semangat penerima reward tersebut. Selanjutnya reward sejumlah Rp 1.000.000 permasing-masing penerima diserahkan. Sebagai bukti telah diserahkan reward, calon mahasiswa beserta orang tua/wali menandatangani bukti penerimaan. Ini menjadi dokumen kegiatan yang dilaksanakan oleh LP3MP.

Pemberian reward ini disadari memang belum mampu membiayaai pendidikan ke perguruan tinggi bagi calon mahasiswa lulus seleksi PTN. Namun perhatian yang diberikan oleh LP3MP dapat meningkatkan spirit bagi masyarakat nagari Taruang-taruang melanjutkan pendidikan sampai ke tingkat Perguruan Tinggi. Spirit ini diharapkan menyebar kepada seluruh masyarakat.

\section{KESIMPULAN}

Pendidikan diyakini sangat penting yang merupakan modal dasar manusia oleh masyarakat Nagari Taruang-taruang Kecamatan IX Koto Sungai Lasi Kabupaten Solok. Keyakinan masyarkat sejalan dengan indikator pembangunan manusia yang dikenalkan oleh Human Development Intex (HDI), yang mengemukakan indikator pembangunan manusia adalah: harapan hidup, perolehan pendidikan dan pendapatan (Mikkelsen, 2003). Pendidikan menjadi faktor penentu kualitas SDM.

Masyarakat dan pemerintah nagari, mengidentifikasi persoalan yang dialami oleh masyarakat dan salah satunya ditemukan rendahnya SDM. Dari sana dirumuskan langkah nyata dengan membentuk LP3MP. Upaya mengidentifikasi persoalan yang dialami masyarakat, bersama-sama mencarikan alternatif pemecahan persoalan, merupakan kegiatan pemberdayaan yang dilakukan sendiri oleh masyarakat, tanpa ada program pemerintah. Kegiatan ini terus berlanjut karena masyarakat menemukan solusi pemecahan persoalan yang ada.

\section{DAFTAR PUSTAKA}

Afrizal. (2008). Pengantar Metode Penelitian Kualitatif; Dari Pengertian Sampai

Penulisan Laporan. Padang: Laboratorium Sosiologi FISIP Unand.

Firdaus, F. (2016). Evaluasi Proyek Pembangunan Sosial Pada Kelompok Masyarakat Kawasan Hutan Mbeliling, Kab. Manggarai Barat, NTT. Jurnal Ilmu Sosial Mamangan, 5(1), 13-22. 
Firdaus, F., Yasin, F., \& Anggreta, D. K. (2015). Penanaman Nilai-Nilai Multikulturalisme Melalui Pendidikan Untuk Menyiasati Masalah Multikultur Di Indonesia\& Malaysia. In R. Saemah, A. Syafrimen, Alias, Y. Faridah, W. A. Jamalulail, I. S. Wekke, ... Z. Mahamod (Eds.), ASEAN Comparative Education Research Conference (ACER-N 2015) (pp. 1755-1767). Selangor, Malaysia: Fakulti Pendidikan, Universiti Kebangsaan Malaysia.

Kurniawati, D. P., Supriyano, B., \& Hanafi, I. (2013). Pemberdayaan Masyarakat di Bidang Usaha Ekonomi (Studi pada Badan Pemberdayaan Masyarakat Kota Mojokerto). Jurnal Administrasi Publik, I(4), 9-14.

Maliki, Z. (2010). Sosiologi Pendidikan. Yogyakarta: Gajah MadaUniversity Press.

Mikkelsen, B. (2003). Metode Penelitian
Partisipatoris dan Upaya-upaya Pemberdayaan. Jakarta: Yayasan Obor Indonesia.

Republik Indonesia, M. H. dan H. A. M. Peraturan Pemerintah Tentang Wajib Belajar, Pub. L. No. 47 (2008). Republik Indonesia.

Republik Indonesia, S. N. Sistem Pendidikan Nasional, Pub. L. No. 20 (2003). Republik Indonesia.

Sidik, F. (2015). Implementasi Program Jaminan Pendidikan Daerah di Kota Yogyakarta. Jurnal Kebijakan \& Administrasi Publik, 19(1).

Ulumiyah, I., Gani, A. J. G., \& Mindarti, L. I. (2013). Peran Pemerintah Desa dalam Memberdayakan Masyarakat Desa (Studi pada Desa Sumberpasir Kecamatan Pakis Kabupaten Malang). Jurnal Administrasi Publik, 1(5), 890899. 